DOI https://doi.org/10.30525/978-9934-26-004-9-134

\title{
ВИХОВНИЙ ПОТЕНЦАЛЛ ТВОРІВ ДЛЯ ДІТЕЙ М. КАРМІНСЬКОГО
}

\author{
Цуранова О. О.
}

кандидат мистеитвознавства, доцент, завідувач кафедри фортепіано

Халєєва О.В.

кандидат мистецтвознавства, доиент, завідувач кафедри вокально-хорової підготовки вчителя Комунального закладу «Харківська гуманітарно-педагогічна академія» Харківської обласної ради м. Харків, Україна

Дитяча музика - невід'ємна складова як мистецького, так i загальноосвітнього процесу виховання підростаючого покоління. Музичні напрацювання композиторів для дітей завжди посідали важливе місце як в їх особистому творчого доробку, так і в системі навчання й виховання, допомагаючи розвивати й окремі якості особистості, i iii загальний потенціал, активізуючи почуття дитини, даруючи їй радість від спілкування 3 прекрасним. Світ дитинства, життя й інтереси дітей завжди були цікавим для композиторів. Практично кожна культурна епоха містить твори для дитячої аудиторії.

Метою дослідження є спроба розглянути творчість М. Кармінського, спрямовану на створення дитячої музики та проаналізувати його фортепіанні твори у контексті української фортепіанної музики для дітей, створеної у XX столітті, а також оцінити ії виховний потенціал.

Аналізуючи творчість композиторів, що належать до різних культурно-історичних епох та національних традицій, слід відмітити наявність у ній окремих творів або циклів дитячої музики, як от: Й. Бах, Р. Шуман, Ж. Бізе, Е. Гріг, К. Дебюссі, П. Чайковський, С. Прокоф'єв, Д. Шостакович, Г. Свиридов та інші. Українські композитори також приділяли значну увагу цьому напряму діяльності. Починаючи з кінця XIX століття, на історичній арені України з'являється ціла плеяда видатних музикантів, твори яких стали джерелом педагогічного репертуару для дітей. Відомі твори для дітей М. Лисенка, М. Калачевського, Петра i Володимира Сокальських, Я. Степового, Н. Нижанківського, В. Косенка, Л. Ревуцького, Г. Беклемішева, 
С. Борткевича, I. Берковича, Г. Орлянського, Л. Альперіна, А. Штогаренка, С. Людкевич, М. Колесси, М. Жербіна, I. Шамо, М. Дремлюги, А. Коломійця, А. Кос-Анатольського, М. Сільванського, В. Подвали, М. Скорика, Л. Колодуба, М. Степаненка, Ж.Колодуб та багато інших. Вписали свої сторінки в жанрову палітру дитячої фортепіанної музики й композитори Слобожанщини - В. Птушкін, Л. Шукайло, О. Глотов та інші. Але окреме місце в цьому переліку належить М. Кармінському (1930-1995), для якого 2020 рік є ювілейним.

Марко Веніамінович народився й усе своє життя провів у Харкові. Закінчив Харківську консерваторію 1953 року, з 1955 року - Член Спілки композиторів УРСР, Заслужений діяч мистецтв УРСР (1980). Творча спадщина митця охоплює різні жанри: симфонічні твори, опери, балет, камерно-інструментальні й хорові твори, пісні та музику до фільмів $\mathrm{i}$ театральних вистав, інструментальна музика, у тому числі для фортепіано. Особливої уваги заслуговують твори композитора для дітей - хорові, вокальні, фортепіанні альбоми, що написані у 70-90-х роках минулого століття. Не випадково саме дитяча тематика набула такої актуальності й живого інтересу в творчості М. Кармінського.

Марко Веніамінович - людина завжди відкрита для спілкування, творчої взаємодії, обміном знаннями й будь-якою культурною інформацією. За згадками Г. Ганзбурга, який близько знав і товаришував 3 композитором, М. Кармінський «володів унікальним даром мистецтвом спілкування $<\ldots>$, залишаючись завжди самим собою, він не пригнічував широтою своїх знань, ніколи не виглядав метром, що прорікав високі сентенції» [1, с. 114].

Уміння спілкуватися з будь-якою аудиторією, призвело до частих творчих зустрічей з дитячими колективами й їх керівниками, вчителями музичних шкіл тощо. Так, Марко Веніамінович декілька разів відвідував й Харківську гуманітарно-педагогічну академію, де радо знайомив майбутніх учителів музики зі своїми творами, особисто їх виконуючи за роялем.

До складу дитячого педагогічного репертуару для фортепіано увійшло декілька збірників композитора, серед яких: «Музика для дітей», «Домашній зоопарк», «27 п’єс у тридольному ритмі», «Строкатий зошит», окремі твори зі спектаклів, сюїт тощо. Твори збірника «Музика для дітей» увібрали в себе більш характерні особливості композиторського письма М. Кармінського, притаманного його особистому музичному мисленню. «Дитячі пісні Кармінського, наголошує Г. Ганзбург, - відрізняє яскрава, по театральному опукла $\mathrm{i}$ помітна образність. Композитор створив свій неповторний театр пісні, 
що переносить дітей у захоплюючий світ казки, фантазії, веселих цікавих пригод, безстрашних героїв, які борються з неправдою і злом» [1, с. 89]. Сказане музикознавцем щодо пісенних опусів композитора, не $\epsilon$ виключенням відносно дитячих п’єс для фортепіано.

Майстерність композитора проявилась у тому, що ці твори зрозумілі й близькі дитячій аудиторії, зручні для виконання. Сам Марко Веніамінович уважав, що тільки діти можуть повною мірою зрозуміти його твори. Програмність, ясність форми та музичної мови пробуджують дитячу увагу, надихають на яскраве виконання. Але головним «кодовим словом», що розкриває секрет звучання музики М. Кармінського $\epsilon$ «театр». Композитор, який так любив і цінував театральне мистецтво, старанно й послідовно писав для сценічних постанов, у своїх інструментальних творах, за відсутністю поетичного слова засобами музичної мови створював зорові, театрально зримі образи.

Усі п’єси «Дитячого альбому», що увійшли до збірника «Музика для дітей», окрім програмної назви мають жанрову спрямованість, а саме: «Улюблена казка: Маленьке рондо», «Ляльки танцюють: Скерцино», «Похід іграшок: Марш», «Старовинна історія: Маленька балада», «Веселий трубач: Гумореска», «Образа: Інтермецо в старовинному стилі», «Осінній день: Сумна полька», «Степом, степом...: Ліричний наспів», «Ми граємо на дворі: Етюд-галоп», «Біля зарослого озера: Прелюдія». У такий спосіб автор допомагає виконавцеві якомога впритул наблизитись до розкриття образу твору, деталізувати його жанрову специфіку.

Жанр фортепіанної мініатюри у Марка Веніаміновича виходить за рамки суто інструментального твору. Його «Ляльки танцюють: Скерцино», «Похід іграшок: Марш», «Веселий трубач: Гумореска», «Ми граємо на дворі: Етюд-галоп» - це невеличкі театральні сценки, казкові герої яких оживають під час виконання. Композитор немовби переносить театральну сцену у площину фортепіанної звукової сфери. Яскраві мелодії фортепіанних творів М. Кармінсього базуються на глибинних вокально-пісенних основах українського міського романсу, що відмічений тонким ліризмом й глибокою психологічністю. Усі твори збірника «Музика для дітей» сповнені дитячою безпосередністю, несуть у собі добро й людяне начало. Це і картини природи («Осінній день: Сумна полька», «Степом, степом...: Ліричний наспів», «Біля зарослого озера: Прелюдія»), і веселі дитячі ігри («Ляльки танцюють: Скерцино», «Похід іграшок: Марш»), і розповіді-казки («Старовинна історія: Маленька балада» «Улюблена казка: Маленьке рондо»), а також яскраві жанрові нариси («Веселий трубач: Гумореска», «Образа: Інтермецо в 
старовинному стилі»). Більшість п'єс циклу написано у мажорних ладах, що створює загальний позитивний настрій циклу в цілому.

Таким чином, твори для дітей М. Кармінського користується заслуженою любов'ю та популярністю у виконавців. У них органічно поєднуються інструктивні i художні задачі, образність змісту i досконалість засобів виразності. Дитячі п'єси М. Кармінського продуктивно впливають на загальний музичний розвиток дітей, виховують у них художнє мислення й смак, творчу уяву.

\title{
Література:
}

1. Воспоминания о Марке Карминском/ сост. Г. И. Ганзбург. Харьков : Каравелла, 2000. 132 с. : фот.

2. Кармінська I. М., Бахмет Т. Б. Кармінський Марко Веніамінович. Енциклопедія Сучасної України. Київ, 2012. Т. 12. С. 348 : фот.

3. Кармінський Марко Веніамінович. Мистецтво України: біогр. довід. / за ред. А. В. Кудрицького. Київ, 1997. С. 288.

DOI https://doi.org/10.30525/978-9934-26-004-9-135

\section{РИСИ ВИКОНАВСЬКОГО СТИЛЮ ФРЕНКА СІНАТРИ}

\author{
Чернова Р. O. \\ випускниия \\ Харківської державної академії культури \\ м. Харків, Украӥна
}

У 1920-х роках XX століття отримала своє розповсюдження манера естрадного співу «напівголосно» під назвою «крунінг». Згідно визначенню, наданому в Оксфордському словнику, крунінг являє собою «спів популярних пісень тихим, низьким, рівним голосом, близько тримаючи мікрофон» [5].

А. Р. Сраносов у праці «Традиційний джаз (від свінгу до сучасного мейнстриму)» зазначає, що «основоположником і майстром техніки “крунінг” є Бінг Кросбі. Можливість посилення звуку через мікрофон в корені змінила вокальні вимоги співаків 1920-х років. Класичні вокально-орієнтовані сценічні голоси були занадто гучними для нового середовища. Стримана, іноді безсила вокальна обробка ритмів і звуків $\epsilon$ найбільш істотною характеристикою крунінгу. Таким чином, пісні 